\title{
Natural Resources, Collective Self- Determination, and Secession
}

\author{
FRANK DIETRICH \\ Heinrich-Heine-University Düsseldorf
}

\begin{abstract}
International law grants states, as representatives of their peoples, the right to use and exploit the natural resources located on their territories. The aim of this paper is to clarify how the doctrine of peoples' sovereignty over natural resources is related to their right to political self-determination. Three different perceptions of this relationship are examined. First, the view that peoples have collective ownership rights over the natural resources to be found on their territories is criticized and rejected. Thereafter, it is argued that instrumentalist reasons fail to explain why a people's right to political self-determination implies sovereignty over natural resources. Instead, it is suggested to consider sovereignty over natural resources a necessary component of a people's authority over the territory where their right to self-determination is realized. The proposed solution provides a sensible framework for dealing with practical issues, as can be exemplified by post-secession conflicts over natural resources.
\end{abstract}

Keywords: collective self-determination, global justice, harm principle, natural resources, secession, territory.

\section{INTRODUCTION}

In international politics it is widely accepted that states are entitled to use the natural resources which are located on their territories to their own benefit. The many conflicts over natural resources we currently witness typically concern specific issues, such as the precise national borders between two countries. That states have sovereignty over natural resources - or rather the peoples represented by states - is hardly called into question by relevant international actors. Furthermore, the assignment of special resource rights to territorially concentrated collectives has a secure basis in international law. Most notably, Article 1 of the two major Human Rights Covenants from 1966 recognizes the right of peoples to political 
self-determination. This right implies, as stated in the same article, the entitlement to freely dispose of the natural resources which are found within the respective territorial units.

By contrast, the philosophical debate has been considering the principle of resource sovereignty mainly from a global justice perspective. Several authors have called into question whether peoples can establish special claims to spatially defined shares of the world's resources while excluding all other human beings. In their view, advantages gained from the unequal distribution of natural resources are morally arbitrary and in need of correction. ${ }^{1}$ However, what has received much less attention in the recent philosophical debate is the rationale for seeing resource sovereignty as an important component of the right to collective self-determination. The aim of this paper is to examine in some detail how both concepts-collective self-determination and authority over natural resources - relate to each other. By clarifying this conceptual link at the theoretical level I also hope to contribute to a better understanding of various practical problems.

The argument is subject to two restrictions. First, within the scope of this paper I cannot address the fundamental objections global justice theorists have raised to the sovereignty rights of states or peoples. Instead I start out from the assumption that the right of peoples to political selfdetermination can be justified and try to elucidate how this right relates to resource claims. The argument will, however, show that recognizing peoples' authority over natural resources is in principle compatible with major demands of global justice. ${ }^{2}$ Moreover, even the critics of the current state system may agree that attempts to establish global political institutions are not likely to succeed in the foreseeable future. Thus, a thorough analysis of the concept of political self-determination may prove to be helpful for reflecting on criteria of justice under non-ideal conditions.

Second, my argument relies on a rather conventional understanding of the term "natural resources". I take natural resources to be materials or substances of some economic value, which exist without the actions of human beings, such as fertile land, minerals, or water. This is not to deny that more sophisticated models that have been recently proposed, e.g. Tim Hayward's (2006) "eco-space conception" or Avery Kolers' (2012) "intentional conception", may provide important insights. Again, it would go beyond the scope of this paper to enter into the current debate on the adequate understanding of natural resources. Although I expect my

1 Criticism of the resource privilege of states or peoples has been offered inter alia by Pogge (2008: 202-221) and Armstrong (2015) and (2017: 132-149).

2 For an instructive discussion of how the ideal of global equality can be reconciled with the right of peoples to political self-determination, see Armstrong (2010). 
discussion of the right to collective self-determination to be relevant for more refined conceptions, I cannot demonstrate this here.

The argument proceeds by three steps. In the second section, I will explore the development of the right of peoples to political selfdetermination - with a special focus on the doctrine of permanent sovereignty over natural resources - in international law. Thereafter, in the third section, I will discuss three possible explanations of how natural resources may be linked with a group's entitlement to independently decide on its common future. First, they may be seen as the common property of a people; second, they may have an instrumental value for the achievement of a people's collectively determined goals; or, third, resource sovereignty may be an essential component of a people's claim to a territory of its own. After having advanced my arguments for the latter view, I will, in the fourth section, dwell on some of its implications. More precisely, I will ask what the proposed interpretation has to say on the handling of competing resource claims, which may emerge in the wake of secession or state dissolution. Finally, in the last section I will briefly summarize the main findings of my analysis.

\section{RESOURCE SOVEREIGNTY IN INTERNATIONAL LAW}

The principle of people's permanent sovereignty over natural resources has its roots in the period of decolonization. Its development was characterized by a conflict of interests between colonial peoples and newly independent states on the one hand and the prosperous states of the West on the other hand. The former actors were anxious to gain political independence and, if achieved, to expand their ability to pursue common goals. Control over natural resources was, in their view, an important precondition for substantial self-determination and successful economic development (Schrijver 2010b: sec. C2). The (former) colonial powers, by contrast, worried about a possible shortage of raw materials and, consequently, detrimental effects on the global economy. Moreover, they feared that the decolonized states might nationalize foreign companies without offering sufficient compensation for their investments.

The emergence of the concept of resource sovereignty in international law was closely connected with the development of a right to collective self-determination. The first significant legal document mentioning the political self-determination of peoples was the Charter of the United 
Nations in $1945 .{ }^{3}$ Article 1.2 of the Charter states:

"The purposes of the United Nations are: ... to develop friendly relations among nations based on respect for the principle of equal rights and self-determination of peoples, and to take other appropriate measures to strengthen universal peace."

There is wide agreement that at this time the self-determination of peoples had to be understood as a guiding principle for the peaceful coexistence of the community of states. However, in the years to come the principle of self-determination quickly developed into a legal right peoples under foreign rule could refer to. A crucial role in this process played Resolution 1514 of the United Nation's General Assembly (UNGA) from 1960, which called for bringing colonization to a speedy and unconditional end. In the so-called Decolonization Resolution the member states of the United Nations unanimously recognized a right of all peoples to selfdetermination. Although UNGA resolutions are not legally binding, they provide evidence of the predominant conception of international law.

The view that a right to self-determination is existent in common law has been further substantiated in the process of decolonization, as many colonial peoples were able to gain political independence by appealing to their right to self-determination. In 1966, when the International Covenant on Civil and Political Rights (ICCPR) and the International Covenant on Economic, Social and Cultural Rights (ICESCR) were established, the right to self-determination was provided with a secure foundation in international treaty law. Both Human Rights Covenants stipulated identically in their Arts. 1.1:

"All peoples have the right of self-determination. By virtue of that right they freely determine their political status and freely pursue their economic, social and cultural development."4

In 1952 two UNGA resolutions for the first time linked the selfdetermination of under-developed countries or peoples with the right to exploit natural resources. Resolution 523 stipulated "that the underdeveloped countries have the right to determine freely the use of their natural resources." Resolution 626 stated "that the right of peoples freely to

3 The principle has been discussed at least since President Wilson's famous "fourteen points" and has been present in the thoughts of Lenin and Stalin but was not included in the regulations of the League of Nations.

4 Evidently, there is a tension between the right of peoples to self-determination and the right of states to territorial integrity as it is enshrined, most importantly, in Art. 2.4 of the United Nation's Charter. The entitlement of some part of a population, e.g. a colonial people, to freely determine its political status is difficult to reconcile with the inviolability of the established borders. 
use and exploit their natural wealth and resources is inherent in their sovereignty and is in accordance with the purposes and principles of the charter of the United Nations." ${ }^{5}$ For two reasons these resolutions met resistance by the USA, Great Britain, and other highly industrialized states. First, these states complained that the interests of prosperous economies to have access to raw materials were not sufficiently taken into account. Second, they were concerned about the resolutions' potential for legitimizing the expropriation of foreign companies and the annulment of concessions. This worry was fueled, most importantly, by the nationalization of the Anglo-Iranian Oil Company, enforced by the then socialist Iranian government in 1951 (Schrijver 1997: 37-49). The main reason for voting against resolution 626 , given by the US delegation, was the lack of any provision for adequate compensation in the case of expropriation (Hyde 1956: 860).

The discussion on resource rights continued during the drafting process of the United Nations' two major human rights covenants. In 1958 the UNGA adopted resolution 1314, which confirmed "that the right of peoples and nations to self-determination ... includes permanent sovereignty over their natural wealth and resources." By this resolution a special commission was established in order to "conduct a full survey of this basic constituent of the right to self-determination." The view that natural resources are a basic constituent of the right to self-determination was reaffirmed in the UNGA declaration 1803 on the permanent sovereignty over natural resources from 1962. Primarily two provisions prompted the Western states - with the exception of France - to vote in favor of this resolution. First, the declaration required of states which expropriate foreign holdings to pay the owner adequate compensation and, second, it stated that foreign investment agreements freely entered by signatory parties shall be observed in good faith (Schwebel 1994: 401-415).

The resolution on the permanent sovereignty over natural resources for the first time addressed an important aspect of internal self-determination, by commenting on the question of who is supposed to benefit from the extraction of resources. According to par. 1, the right to dispose of a country's natural wealth and resources must be exercised in the interest of "the well-being of the people of the state concerned". This is an important clarification, as experience has shown that in many cases the ruling elites

5 According to Schrijver (2015: 23-24), the term "natural wealth" refers to the resource basis as distinguished from the natural resources themselves. For instance, the forest and the fertile soil constitute (part of) a country's natural wealth, whereas the timber of the trees and the tea or coffee plants count as natural resources. 
have commercially exploited the raw materials to their own advantage. ${ }^{6}$ The resolution on peoples' permanent sovereignty over natural resources paved the way for the inclusion of resource rights in the two human rights treaties of 1966. Both the ICCPR and the ICESCR state identically in their Arts. 1.2:

"All peoples may, for their own ends, freely dispose of their natural wealth and resources without prejudice to any obligations arising out of international economic co-operation, based upon the principle of mutual benefit, and international law. In no case may a people be deprived of its own means of subsistence".

In more recent debates on peoples' permanent sovereignty over natural resources two topics have come into focus. First, the right to extract and make use of natural resources has increasingly been placed in the context of environmental protection. In 1972 the Stockholm Declaration of the UN Conference on the Human Environment for the first time specified obligations entailed by peoples' resource sovereignty. Principle 21 of the Stockholm Declaration specifies:

"States have ... the sovereign right to exploit their own resources pursuant to their own environmental policies, and the responsibility to ensure that activities within their jurisdiction or control do not cause damage to the environment of other States or of areas beyond the limits of national jurisdiction". ${ }^{8}$

While the Stockholm Declaration was mainly concerned with the prevention of external damage, later UN documents entertained a more comprehensive view of environmental protection. A crucial role for the development of international environmental law played the concept of "sustainable development", which was introduced by the so-called Brundtland Commission in 1987. ${ }^{9}$ The goal of sustainable development has been cited in many international legal documents, thereby constraining the right of peoples to exploit their natural wealth and resources (Schrijver 2010a: 59-66). A telling example is the preamble of the UN Convention on

6 The moral responsibilities of other states with regard to governments who fail to manage natural resources in the interests of their peoples are discussed in Wenar (2008) and (2016: 281-334), see also Haugen (2014).

7 Art. 25 (ICESCR) and Art. 47 (ICCPR) state in unison: "Nothing in the present Covenant shall be interpreted as impairing the inherent right of all peoples to enjoy and utilize fully and freely their natural wealth and resources."

8 The wording of this principle is reiterated - with only one slight alteration - in principle 2 of the Rio Declaration on Environment and Development from 1992.

9 The Brundtland report defines sustainable development as "development that meets the needs of the present without compromising the ability of future generations to meet their own needs." 
Biological Diversity from 1992, where the contracting parties reaffirm "that States have sovereign rights over their own biological resources [and ...] are responsible for conserving their biological diversity and for using their biological resources in a sustainable manner." 10

Second, the intrastate allocation of the entitlement to exploit natural resources has become an important concern of international law. A growing body of legal documents has recognized that the doctrine of permanent sovereignty over natural resources applies to indigenous communities. Most importantly, the United Nations Declaration on the Rights of Indigenous Peoples from 2007 states in Art. 3: "Indigenous peoples have the right to self-determination. By virtue of that right they freely determine their political status and freely pursue their economic, social and cultural development." Furthermore, Art. 26.1 states: "Indigenous peoples have the right to lands, territories and resources which they have traditionally owned, occupied or otherwise used or acquired." It is now a widely shared view in international law that different peoples within one state may possess rights over different territories and the respective resources (Miranda 2012: 806-828, Pereira and Gough 2013: 20-34). Thus, states are not only obliged to manage the natural resources which are located within their borders in their citizens' interests; they must also take into account that the population may consist of several peoples, each with its own resource rights. ${ }^{11}$

\section{RESOURCE RIGHTS AS BASIC CONSTITUENT OF COLLECTIVE SELF-DETERMINATION}

The previous section has shown that international law conceives of resource sovereignty as an integral part of peoples' right to political selfdetermination. However, neither the relevant legal documents nor the drafting process that preceded their ratification make sufficiently clear how these concepts are connected with each other. In the following, I will discuss three possible explanations why an entitlement to collective selfdetermination might imply resource rights. First, I will deal with the understanding that self-determining entities have property rights (or similarly created sovereignty rights) to the natural resources of a given

10 A normative argument for the restriction of peoples' permanent sovereignty over natural resources by environmental standards is presented in Gümplová (2014).

11 As a further problem area one might mention resource sovereignty in occupied territories, which has been addressed by the International Court of Justice in several decisions, e.g. the Israeli Wall Advisory Opinion of 2004 and the Armed Activities Case (Congo v. Uganda) of 2005. For a detailed analysis, see Dam-De Jong (2015). 
territory. Subsequently, I will explore instrumentalist accounts according to which a group's capacity to exert its self-determination right crucially depends on the availability of natural resources. After having outlined the main shortcomings of these views, I will argue for considering sovereignty over natural resources a necessary component of a people's authority over the territory where its self-determination takes place. Finally, I will discuss two objections that may be raised to my position.

\subsection{Property and Quasi-Property Rights}

The legal documents on peoples' self-determination rights, which I discussed in the second section, recurrently speak of "their" natural resources. The use of the possessive pronoun "their" might indicate the existence of a collective property right, which predates the right to political selfdetermination. According to this assumption, sovereignty over natural resources is not to be understood as an enabling condition for the exercise of the right to political self-determination. The exploitation (or conservation) of natural resources is rather within the scope of issues on which a people, by virtue of its ownership, is entitled to decide. Like an individual may determine the use of the goods she owns, the members of a people may jointly determine the use of their common possessions. ${ }^{12}$

An important challenge for an ownership account is to explain how collectives, such as peoples, acquire property rights over natural resources. In classical political thought, basically two mechanisms of how property rights come into existence - by first appropriation of previously unowned objects or by mixing one's labor with such objects - are discussed. The historic versions of both theories start out from the assumption that God has devoted his creation to the whole of humanity. The original common possession of entire mankind is then, by a series of individual acts, transformed into a system of private ownership. According to a first appropriation account, as defended for instance by Hugo Grotius, a person who is first to settle on a hitherto uninhabited area acquires a property right to the land and its natural resources. By contrast, the core idea of the labor mixing account, which was initially advanced by John Locke, is that from the very beginning everybody is the owner of herself. If a person invests labor in a natural good, she merges this good with a part of her body, which already constitutes her individual property. Thereby she significantly increases the value of the good concerned and excludes the

12 To be clear, a collective ownership right - as I understand the term here - does not entitle each member of the collective to use the goods concerned at her discretion. Instead the ownership right is held by the group as a whole: the individuals belonging to the group or their representatives must decide jointly-by a majority vote or some other procedure - on how to exercise this right. 
rights of all other people to make use of it. ${ }^{13}$

From the perspectives of both theories only individuals are capable of acquiring property rights - either by first seizing previously unowned goods or by investing labor in them. Hence, the crucial question is how a people can come into the rightful possession of all natural resources located on the territory where it exercises its political self-determination. A possible answer is that the individuals who first acquired property rights over natural resources acted on behalf of the people. Think, for instance, of a ship's captain who discovers a previously unknown island and who declares, when going ashore, to take possession of this island in the name of, let us say, Spain. ${ }^{14}$ Although a first appropriation of natural resources by a people's representative is conceivable, it can, at best, provide part of an explanation. The example of the ship's captain presupposes the existence of a Spanish state, which already has authority over a territory and its natural resources. Even if one admits that the ship's captain was entitled to seize the island on behalf of the Spanish people, it is still unclear how this people's claim to collectively own the natural resources of the Spanish heartland could be justified.

Another response to the here discussed problem is that the individual members of a people voluntarily transferred their property rights over natural resources to the collective. Seemingly, John Locke (1960 [1689]: II $\$ 120)$ comes close to such an idea when he declares: "By the same Act ... whereby any one unites his Person, which was before free, to any Commonwealth; by the same he unites his Possessions, which were before free to it also." However, what Locke has in mind is - I think - that the persons concerned submit their property to the jurisdictional authority of the state. In his view, the individuals in the state of nature have strong reasons to enter into a political society in order to obtain protection for their possessions. Therefore, they are prepared to vest the state with as much jurisdictional authority as necessary (and as little as possible) for the performance of its protective function. It is, however, hard to see why the persons who join a political society should transfer their property rights over natural resources completely to the state, or rather to the people constituting the state. They have no reason to relinquish their property rights because it is precisely the secure enjoyment of their possessions what motivates them to establish a state in the first place. At most, they might grant the state limited rights of intervention, such as the competence

13 For a recent revitalization of Grotius' theory, see Risse (2012: 89-129); for a detailed examination of Locke's argument, see Simmons (1992: 222-306).

14 In a different context, Locke (1960 [1689]: II \$28) admits the acquisition of property at the behest of another person by stating: “(...) the Turfs my Servant has cut (...) become my Property, without the assignation or consent of any body". 
to raise taxes in order to finance police services. However, since they would not assent to substantial intrusions into their private property, the state would not obtain anything close to a collective ownership right. ${ }^{15}$

More recently, an argument has been advocated that may be understood as a culturalist modification of Locke's labor mixing approach. So called liberal nationalist authors, such as David Miller (1995: 21-27, 2007: 214-230 and 2012), Chaim Gans (2003: 97-123), and Tamar Meisels (2009), have pointed out to the formative influences the culture of a nation exerts on a territory. ${ }^{16}$ The members of a national community employ specific forms of agriculture, build roads and ports, and establish particular settlement structures. These cultural activities leave a lasting imprint on the territory, which distinguishes it from other geographical places. Persons identifying with a national community typically have strong emotional bonds to the area they regard as their homeland. Since the territory is shaped by their culture and closely connected to the nation's history, they cannot imagine realizing their collective self-determination anywhere else. ${ }^{17}$ By analogy with Locke, it has also been argued that the national community put the piece of land it traditionally occupies to an efficient use. Over time, the various cultural activities of the group add material as well as symbolic value to the land (Meisels 2009: 97-112 and Miller 2012: 257-262). ${ }^{18}$

From a liberal nationalist perspective, the above considerations cultural formation, emotional attachment, value enhancement-legitimize the claims of nations to "their" territories. It is important to note that, contrary to Locke's account, territorial rights are not conceived of as collective ownership rights. Instead, national communities are thought to have an entitlement to exert jurisdictional authority over their traditional

15 For a critical examination of Locke's property theory of territorial rights, see Beitz (1980).

16 It may be worth noting that the above-mentioned theorists speak of "nations" or "national communities" instead of "peoples". For the question under discussion - the link between collective self-determination rights and sovereignty over natural resources - this terminological difference seems, however, irrelevant.

17 As regards personal attachment, Miller (2007: 219) states: "The case for having rights over the relevant territory is (...) straightforward: it gives members of the nation continuing access to places that are especially significant to them, and it allows choices to be made over how these sites are to be protected and managed".

18 The theory of resource rights advocated by Cara Nine (2012: 137-141) borrows from different aspects of Locke's political thought. In her view, a group acquires resource rights when it uses the resources concerned in a value-generating way, whereby she considers the achievement of political justice the relevant value. 
areas of settlement. ${ }^{19}$ The liberal nationalist's argument has the advantage of avoiding the problem with which Locke's appropriation theory has to grapple. Since the labor, which needs to be "mixed" with the land, is understood as the joint activities of a culturally defined nation, the creation of a collective right seems more plausible. It is not the work of particular individuals but the common and ongoing efforts of a nation that shape some piece of land and, thereby, establish a claim to it. Hence, the culturalist reinterpretation of Locke's account need not explain how individual rights can be transformed into collective rights of a nation or a people.

The liberal nationalist's argument for sovereignty over natural resources faces, however, a serious problem. It needs to be shown how the cultural activities of national communities, on which their territorial claims depend, bear on natural resources. To be sure, the agricultural and settlement practices of national communities may shape the surface of the land and create strong feelings of belonging. Moreover, certain natural resources, such as coal or diamonds, and the transgenerational project of their exploitation may play an important role for a national culture (Miller 2012: 263-264). However, a people's sovereignty over natural resources is generally understood to comprise the whole range of raw materials that are situated within the relevant territory. Evidently, the members of a nation neither invest labor in every natural resource nor are they emotionally attached to every natural resource. For instance, the wood of an unmanaged forest and the water of a small, untouched river are not subject to any cultural activity. Furthermore, it is hard to see on which grounds a people might claim a right to the future use of still undiscovered resources. The above-sketched reinterpretation of Locke's appropriation argument cannot extend to resources into which no cultural labor has been invested.

In sum, the here discussed account may, at best, justify the claim of national communities to exert their right to political self-determination on a particular territory. ${ }^{20}$ However, even if territorial rights can be established in principle, the question which competences these rights include still has to be settled. In the philosophical debate it has been widely taken for granted that the justification of a territorial claim encompasses the whole

19 The jurisdictional authority of a people includes the competence to establish and modify a system of property rights on the territory concerned. Thus, a people (or its political representatives) may decide to nationalize natural resources or to allow private property rights. For an important critique of the conflation of "property rights" and "sovereignty rights" in current nationalist debates, see Fleischacker (2013).

20 For a critical examination of the liberal nationalist's justification of territorial claims, see Dietrich (2011: 87-89). 
set of rights conventionally attributed to states. ${ }^{21}$ But the reasons that can be given for the substantiation of a territorial claim do not necessarily apply to each of its standard components. The liberal nationalist's argument fails to explain why a group's right to political self-determination entails an entitlement to dispose of (the full range of) natural resources.

\subsection{Instrumentalist Arguments}

As set out in the second section, the right of peoples to political selfdetermination emerged in the period of decolonization. At this time the freedom of newly created state communities to decide on their economic, social and cultural development was high on the agenda. Against this background, important legal documents refer to natural resources as means for the achievement of peoples' independently chosen goals. Most notably, Articles 1.2 of the ICCPR and the ICESCR state: "All peoples may, for their own ends, freely dispose of their natural resources". This formulation points to the instrumental value of natural resources for the exercise of the right to collective self-determination. Contrary to the interpretation discussed above, peoples do not acquire property rights (or similarly created jurisdictional rights) over natural resources by the work they invest on a given territory. Instead, they can claim authority over natural resources because their right to political self-determination would be void if an adequate material basis were lacking. ${ }^{22}$

The capacity of a people to make significant choices with regard to its common future depends, at least in part, on its prosperity. Roughly speaking, the more affluent a collective is, the more goals are attainable between which its member can freely decide. The revenues, which can be generated from the exploitation of natural resources, will normally enhance a people's set of options. It seems, however, plausible to assume that the right to political self-determination only requires the availability of a minimum amount of alternatives. In order to make collective decisions, a people must be capable of choosing between different economic, social or cultural goals. Meaningful self-determination does not require a particularly extensive set of options and is consistent with considerable

21 For a standard definition of territorial rights that encompasses authority over natural resources, see Simmons (2001: 306).

22 A different instrumentalist argument for the permanent sovereignty of peoples over natural resources was presented by John Rawls (1999: 38-39) in "A Law of Peoples". According to Rawls, a sustainable management of natural resources can best be achieved by assigning territorial rights to specific agents. If a people has exclusive responsibility for a certain piece of territory, it will be interested in the long-term exploitation of the resources concerned and refrain from overexploitation. Since Rawls is mainly concerned with the preservation of the environment - rather than the economic preconditions for collective self-determination - I will not discuss his argument in more detail. 
wealth disparities between the right-holders. In this context, it should be recalled that Articles 1.2 of the two human rights covenants state: "In no case may a people be deprived of its means of subsistence". The reference to the means of subsistence supports the view that the relevant regulations of international law focus on the basic prerequisites for the exercise of the right to self-determination.

Evidently, the instrumentalist interpretation must rely on an empirical assumption about the significance of natural resources for a people's economic welfare. The research literature on the comparative development of resource-rich and resource-poor countries casts, however, doubts on the correctness of this thesis. To begin with, it seems questionable whether control over natural resources is necessary for achieving a minimum level of economic prosperity. There are other important factors, such as technological knowledge and the stability of political institutions, which contribute significantly to a people's wealth..$^{23}$ Thus, even a political community that widely lacks valuable raw materials may be able to generate the necessary economic means for exerting its self-determination right. Moreover, in the case of developing countries natural resources, such as oil and gemstones, have often proved to be a serious obstacle to economic progress. High resource income tends to increase government corruption and to help authoritarian regimes to ward off pressure for democratic reform. Competition for resource revenues is also likely to trigger violent intrastate conflicts, which impede a country's economic development. In sum, what has become known as "resource curse" speaks against a positive correlation between wealth in resources and a people's capacity for self-determination. ${ }^{24}$

On a more theoretical level, the here considered interpretation of peoples' permanent sovereignty over natural resources faces three closely related problems (Armstrong 2017: 142-143). First, what the instrumentalist account can establish is, at best, that self-determining collectives are in need of a certain amount of economic means. It fails, however, to give any reason why peoples have special claims to the natural resources that can be found on their respective state territories. Of course, it may appear obvious to specify the right holders' claims in accordance with the existing state borders. But it is not the instrumental value of natural resources for the right to political self-determination that explains the link to a particular territory. The precise location of the natural resources a people has at its

23 John Rawls (1999: 113-120) restricted duties of international assistance to the building of stable institutions because he deemed this to be the most important precondition for a country's economic development.

24 The term "resource curse" has been introduced by Richard Auti (1993); an overview over recent research is given, for instance, in Ross (2015) and Venables (2016). 
disposal is largely irrelevant for its capacity to take its own decisions. In principle, people A could be enabled to exercise its right to selfdetermination by granting it a claim to the resources of people B's territory, and vice versa.

Second, I have argued above that the right to political self-determination should be understood as a threshold concept, requiring only the availability of a minimum amount of choices. If this is correct, the instrumentalist view can only succeed with explaining why peoples need natural resources (or other sources of income) to an extent necessary for realizing a basic set of options. It provides, however, no reason for granting self-determining collectives authority over the total amount of natural resources that are located on their territories. The claims of peoples to natural resources, which are, strictly speaking, not indispensable for exercising their rights to self-determination, must rely on a different justification.

Third, natural resources and the chances of profiting from their exploitation are very unequally distributed across the globe. According to the instrumentalist interpretation, peoples are entitled to the natural resources necessary for exercising their rights to political selfdetermination. This implies that each right holder should have access to a certain amount of valuable raw materials, even if the territory under its control lacks significant deposits. The instrumentalist account thus mandates the reallocation of natural resources, or of the revenues derived from their exploitation, in order to enable less well-equipped peoples to exert their rights to political self-determination. As a consequence, it cannot provide a general justification for peoples' permanent sovereignty over the whole set of natural resources located on their state territories. Peoples who have authority over more commodities than required for their self-determination are duty-bound to share their resource wealth with less fortunate right holders.

\subsection{Territorial Rights}

A more promising interpretation of peoples' permanent sovereignty over natural resources is suggested by the efforts of colonial peoples to effectively end their domination by Western states. The independence movements were particularly concerned that the former colonial powers would continue to exert a strong influence on their newly established states. Sovereignty over natural resources was a sensitive issue insofar as foreign state or private companies had made significant investments in their exploitation. The colonial peoples considered their political selfdetermination to be substantially impaired if other actors had decisionmaking powers over (some part of) the natural resources situated within 
the borders of their designated state territories. Their misgivings about a continued domination find, inter alia, expression in Par. 2 of UNGA resolution 1803:

"The exploration, development and disposition of ... resources, as well as the import of the foreign capital required for these purposes should be in conformity with the rules and conditions which the peoples and nations freely consider to be necessary or desirable with regard to the authorization, restriction or prohibition of such activities".

The colonial peoples' demand for non-domination draws attention to the crucial interest the right to political self-determination aims to protect. By granting this right in international law, the collectives concerned are supposed to be enabled to take independent decisions on their common future. However, a people cannot freely pursue its particular social, economic and cultural goals unless it has control over some piece of territory. It needs a clearly defined space where it can - undisturbed by other actors - implement its political decisions. If third parties pursuing conflicting goals were entitled to decide on the use of the territory concerned, a people might be unable to accomplish its common objectives. The territorial dimension of the right to political self-determination provides the key for understanding the conceptual link to the principle of resource sovereignty. Since a people's right to political self-determination implies authority over some territory, it necessarily extends to the natural resources that are located within its borders (Moore 2015: 173-176).

To illustrate the argument outlined above, it may be helpful to imagine a situation when a people's right to self-determination would not comprise full authority over a defined territory. Think, for example, of an international company or some global institution having decision-making power over the extraction of coal within the state boundaries. The members of the people living on the territory may predominantly oppose coal mining, as it contradicts their own values, plans and projects. They may, for instance, attach great importance to the protection of the environment and the preservation of traditional settlements in the mining area. However, a majority decision to declare the region a natural reserve would be impossible to effectuate if some other actor were permitted to access the coal deposits. Consequently, assigning the right to decide on the exploitation of natural resources to a third party would seriously impair a people's capacity for self-determination.

The here proposed interpretation has important consequences for the specification of the resource rights to which a self-determining collective is entitled. A people cannot exercise its right to political self-determination in a meaningful way unless it has authority over some piece of territory. 
Therefore, it must have decision-making power over the exploitation (or conservation) of the natural resources located on the territory concerned. However, a people's right to political self-determination does not imply a claim to the total earnings that can be derived from the natural resources. Thus, contrary to the conventional view in international law, a people's right to political self-determination entails control rights over natural resources but fails to justify (the full set of) income rights. ${ }^{25}$

Restricting the scope of peoples' permanent sovereignty over natural resources to control rights allows for reconciling this doctrine with demands of global justice. Thomas Pogge (2008: 210-214), for instance, has proposed to introduce a "global resource dividend" as a mechanism for reducing the unequal distribution of wealth within the world population. According to Pogge, states should be permitted to make sovereign decisions on the exploitation of the natural resources that are located on their territories. However, if they decide to extract oil or other raw materials, they are required to transfer some percentage of their revenues to the global poor. Since the "global resource dividend" does not deny the control rights of self-determining collectives, it is fully compatible with the abovesketched understanding of peoples' permanent sovereignty over natural resources. It is important to note that I do not intend to make a case for the theory of global justice defended by Pogge or some other author. Within the scope of this paper, I cannot argue for or against a moral duty to redistribute wealth across national boundaries. I merely wish to point out that there is no fundamental contradiction between demands of global justice and the resource sovereignty of peoples.

Since control rights are at the core of the here defended view of resource sovereignty, it seems worthwhile to elaborate on their content and scope. ${ }^{26}$ The right of peoples to political self-determination has to be understood as a prima facie right which can be trumped by conflicting moral considerations, such as the harm principle (Schuppert 2014: 76-77, Angeli 2015: 98 and Stilz 2016: 100). By way of illustration, imagine a state that tests nuclear weapons in a desert region in close vicinity to a densely populated neighboring country. Clearly, the people's right to take independent decisions on its defense policy does not include an entitlement to endanger the life and health of third parties. Since control rights over natural resources are closely connected to the ideal of political self-determination, they must be subject to the same restrictions.

25 The distinction between control rights and income rights over natural resources has also been emphasized by Angeli (2015: 131-132) and Moore (2015: 173-176).

26 I am grateful to an anonymous referee of this journal for urging me to clarify the concept of control rights. 
Consequently, peoples lack authority over natural resources if their exploitation (or conservation) inflicts harm on persons living outside the country. ${ }^{27}$ Of course, decisions on the extraction of raw materials normally do not cause immediate damage to third parties, as in the example of the nuclear weapons test. The use of natural resources can, however, substantially worsen the living conditions of other persons in an indirect manner. A people may, for instance, significantly contribute to the devastating effects of global warming by authorizing the deforestation of rainforests or the extraction of fossil fuels.

In order to determine the restrictions that need to be placed on peoples' control rights over natural resources more precisely, two goals have to be considered. First and foremost, third parties must be protected from the harm self-determining collectives may inflict on them. The right to political self-determination includes neither a permit to damage other communities nor to expose them to serious risk. Second, a people's capacity to realize its specific social, economic and cultural ambitions should be maintained to the widest possible extent. If there are two or more options of how the control rights of a people can be effectively constrained, the one that has the least negative impact on its political autonomy should be adopted.

For a proper understanding of the first goal, it is necessary to dwell on the concept of harm. Joel Feinberg (1986: 145-146, original emphasis) proposed to

"think of harming as having two components: (1) It must lead to some kind of adverse effect, or create the danger of such an effect, on its victim's interests; and (2) it must be inflicted wrongfully in violation of the victim's rights".

Regarding the first component, a curtailment of individual or collective autonomy can only be justified if the neglect of other parties' interests is significant. ${ }^{28}$ As the self-determination of an individual would be overly reduced if it were not allowed to pose relatively small risks on other actors, e.g. by driving a car, the political self-determination of a collective would be unduly diminished if it were required to rule out any possible negative externalities. Of course, it is difficult to state with any precision what extent of risk and damages other persons or groups must accept. It seems, however, to be clear that every assessment of the harm peoples may inflict on third parties has to take three aspects into account. The evaluation has

27 Moreover, the right to political self-determination does not license a people to violate the basic interests of minority groups who live within the state boundaries.

28 According to Barboza (2011: 99-102), it is generally accepted in international law that an imposition of minor risks and damages has to be tolerated by the states concerned. 
to consider the magnitude of the damage, the likelihood of its occurrence, and - in cases of several actors sharing responsibility - the contribution of a specific people. The higher a people's resource utilization scores on these criteria, the stronger is the argument for limiting its control rights.

Regarding the second component, Feinberg (1984:218-221) emphasized that individuals often pursue competing goals, which they cannot realize without thwarting the interests of other parties. For instance, the successful sales strategy of shopkeeper A may cut the profits of shopkeeper B who loses a great number of customers. A's conduct is, however, fully legitimate - she does not wrong B - and fails, therefore, to violate the harm principle. Likewise, state decisions placing other actors at a competitive disadvantage normally do not constitute harm in the relevant sense. By way of illustration, think of a country $C$ that hitherto has been the only exporter of a valuable raw material. If another country started to extract and sell the same resource, $\mathrm{C}$ would not be wronged, although its economic situation might deteriorate as a result of falling prices.

Finally, one may wonder whether peoples who refrain from extracting resources can inflict harm on third parties. The standard case of harm involves an action of party A that has a negative effect on party B, e.g. by causing an injury. Omitting an action, such as the extraction of resources, leaves the living conditions of other persons unchanged and does not worsen their situation. However, it is widely accepted that A's omission of an action can harm B if A is obliged to perform this action. Think, for example, of a physician who fails to provide a patient with an urgently needed treatment because she does not want to be late for her dancing class. In this case, the patient is put in a worse position compared with the counterfactual scenario in which the physician had fulfilled her duty (Feinberg 1986: 148-150). Consequently, a people could harm third parties by abstaining from the exploitation of natural resources if it had a duty to make these resources available. ${ }^{29}$

As regards the second goal, it has to be examined more closely how the different forms the restriction of its control rights might take can affect a people's capacity for self-determination. Above all, two aspects - the content of the limitation and the kind of competences which are conferred on other actors - need to be discussed. First, it makes an important difference whether a people is obliged to preserve or to extract (some part of) the natural resources located on its territory. The forced conservation

29 One may think of a duty to provide the world economy with scarce resources (see section 2) or a duty to transfer resource revenues to the global poor. The substantiation of any such duty can, however, be expected to be much more controversial than the justification of the harm principle. 
of natural resources confines a people's space of action but normally leaves many other options open. If a people is, for example, prohibited from exploiting a coal deposit, it still can take independent decisions on the use of the area concerned. Typically, there will be several possibilities declaring a natural reserve, erecting new settlements, establishing an industrial zone - the political representatives can choose from. By contrast, the forced extraction of natural resources requires a specific action that may exclude every other option. In particular, large-scale projects, such as coal mining, profoundly affect the relevant area and allow of no additional usages a people could decide on.

Although prohibitions on the extraction of natural resources are usually less detrimental to peoples' capacity for self-determination, it should not go unnoticed that their impact can vary greatly. The forced conservation of raw materials tends to weaken the political autonomy of developing countries much more than those of highly industrialized countries. In many cases, the export of natural resources provides an important source of income for the inhabitants of developing countries. If they are banned from selling valuable raw materials, their revenues and consequently their set of options will be significantly reduced. By contrast, technologically advanced societies normally have other possibilities to generate the financial means in order to pursue important collective goals. Therefore, the imposition of a duty to preserve (some) natural resources has to take the economic situation of the peoples concerned into consideration. If their potential for self-determination is impaired to a greater degree, prohibiting the exploitation of natural resources requires a stronger justification. ${ }^{30}$

Second, a people's political autonomy also depends on the kind of competences that are conferred to other actors. On the one hand, some global or multilateral institution could be authorized to establish rules regulating the use of raw materials. Thereby, it would have decisionmaking power over the exploitation or conservation of the natural resources in question. The agents of the institution would, however, not be allowed to implement or enforce its regulations within the territory of a people. On the other hand, some external authority could be entitled to directly access the raw materials over which it enjoys control rights. In this case, its agents would be free to enter a people's territory and to organize

30 Although Armstrong (2017: 233-238) is not much concerned with the political selfdetermination of peoples, he makes a similar point regarding the welfare of their members. Poor societies who are required to leave (part of) their natural resources unexploited can, in his view, legitimately claim compensation for the loss of development opportunities. 
the extraction of natural resources or to safeguard their preservation. ${ }^{31}$

Granting some global or multilateral institution the right to operate on the territory of a people would have the most negative impact on its capacity for self-determination. The application of norms regulating the use of natural resources normally leaves the political representatives of a people with some scope of discretion. This residual decision-making power would be lost if an external authority were directly responsible for the exploitation (or conservation) of the raw materials in question. Moreover, the right to manage part of the natural resources on a people's territory may entail additional competences in other policy fields. For instance, in order to successfully run a coal mining project it may be necessary to develop the transport infrastructure and to admit skilled workers. Arguably, an external actor who is entitled to initiate the extraction of coal must also have a say in a country's transport and migration policy. As a consequence, the self-determination of a people would be restricted in a number of spheres only indirectly related to the use of natural resources.

If the relevant international authority is prohibited from entering a people's territory, much depends on how its regulations are formulated. Peoples who have to conform to general standards typically enjoy some degree of discretion, whereas peoples who have to follow more specific instructions widely lack decision making power. For instance, a country, which is required to produce a certain amount of natural gas per annum, may still be able to take independent decisions on the development of deposits or the prohibition of drilling technologies. Likewise, a country, which is obliged to preserve eighty percent of its rainforests, can freely determine the areas where a protection zone shall be established. Since general norms allow for different specifications, they enable (to some extent) the political representatives of a people to bring important collective goals and values to bear. By contrast, more detailed directives of an external authority deprive peoples of the possibility to decide in accordance with their own preferences.

In sum, restrictions of control rights necessarily diminish a people's political autonomy and require, therefore, a sufficiently strong justification. The most widely accepted reason for constraining control rights is provided by the harm principle, which prohibits a people from damaging third parties. Arguments for (or against) the limitation of control rights have to consider the seriousness of the harm and possible impacts on a people's capacity for self-determination. As explicated above, the forced extraction

31 In addition, Schuppert (2014: 87-94) has proposed to establish an International Court of the Environment authorized to make binding judgements on disputes concerning the use of natural resources. 
of natural resources tends to reduce a people's decision-making power to a greater extent than the forced conservation of natural resources. Consequently, regulations imposing an obligation to exploit natural resources must be supported by stronger harm-related reasons. Conferring to an external authority the right to access natural resources directly has the most negative impact on a people's capacity for self-determination. Such a curtailment of a country's territorial integrity can only be justified in exceptional cases when peoples are constantly unwilling or unable to comply with international norms. ${ }^{32}$

\subsection{Two Objections}

Finally, I will discuss two objections that may be raised to the here defended interpretation of peoples' sovereignty over natural resources. A weakness of the above given argument may, first, be seen in the fact that I have characterized the right to political self-determination as a threshold concept. In subsection 3.2, I have maintained that the members of a selfdetermining collective only need a minimum amount of alternatives between which they can freely decide. If a people lacks authority over the exploitation of (part of) the natural resources on a given territory, its set of options is thereby restricted, but it may still be able to choose between a variety of competing goals. Therefore, one may object that my understanding of the principle of resource sovereignty is compatible with assigning quite extensive control rights to other actors. Even restrictions, which do not protect third parties from harm, may appear to be justified as long as they remain below the critical threshold. ${ }^{33}$

Here it is important to note that the right to collective self-determination - like the right to individual self-determination - consists of two elements. The right holder must, first, possess a sufficient number of options and, second, be free from external coercion. ${ }^{34}$ For instance, the selfdetermination right of a patient would be seriously violated if a physician forced her to undergo a certain treatment. This would also be true if she were able to choose between many qualitatively different options outside the medical context. Likewise, granting a third party authority over natural resources may leave a people with the opportunity to decide many other social, economic and cultural issues. However, the entitlement of some

32 For a brief examination of "ecological interventions", see Schuppert (2014: 84-85).

33 A related criticism is discussed and rejected in Banai (2016: 17-18).

34 As regards the violation of individual autonomy, Raz (1986: 377) states: "Coercion diminishes a person's options. It is sometimes supposed that that provides a full explanation of why it invades autonomy. It reduces the coerced person's options below adequacy. But it need not. One may be coerced not to pursue one option while being left with plenty of others to choose from." 
foreign actor to control the use of raw materials located on the territory of a people runs contrary to this people's right to collective self-determination. For instance, thwarting the goal to preserve natural habitats or traditional buildings by mandating the extraction of coal clearly amounts to a form of alien domination.

A second objection that may be raised to the here proposed concept of resource sovereignty concerns the hogging of natural resources. Peoples enjoying self-determination rights may decide against extracting raw materials that could be used to alleviate poverty in other world regions. In view of the plight of destitute persons, one may doubt whether peoples who control valuable resources should be entitled to abstain from their exploitation. In response to this concern I would like to emphasize that my understanding of resource sovereignty does not preclude a duty to extract natural resources. Given the adverse effects of such a duty for the political autonomy of the people concerned, its imposition has to be supported by weighty reasons. Whether or not the forced extraction of natural resources can be justified ultimately depends on issues of global justice I cannot discuss within the scope of this paper.

Moreover, it should be noted that my concept of peoples' sovereignty over natural resources is in principle compatible with theories of global justice, which call for the taxation of resource ownership. Most importantly, Hillel Steiner (1994: 266-282 and 2011) argued that states whose inhabitants appropriated more than an equal share of the world's natural resources owe compensation to states whose members under-appropriated the world's natural resources. These states are required to pay a tax to a global fund, which shall be based on the rental value of their territories. ${ }^{35}$ Evidently, the authorization of a global fund to levy taxes on resource ownership would interfere with peoples' self-determination rights. However, the political representatives of a people would not be obliged to effect the extraction and sale of any raw materials located on the relevant territory. Provided that they had other sources of income enabling them to pay the tax, they could still opt for the conservation of natural resources. ${ }^{36}$

It seems, however, worth noting that the establishment of a global fund, as proposed by Steiner, meets with two criticisms. First, to what extent a tax on resource ownership would diminish a people's capacity for selfdetermination depends very much on its economic situation. For poor

35 According to John Locke's theory of just appropriation, the tax disregards any improvements of the land and the natural resources located on it, which have been achieved through the investment of labor.

36 For a proposal to combine Pogge's and Steiner's theories by taxing the use and the ownership of natural resources, see Casal (2011a and 2011b). 
peoples it may be difficult, if not impossible, to pay the tax unless they exploit (part of) their natural resources, whereas rich peoples may still be able to decide in favor of resource conservation. Hence, in terms of selfdetermination destitute peoples would be unfairly burdened by a global fund. Second, the imposition of a tax on consumption, as advocated by Pogge, would provide sensible incentives for a sustainable use of natural resources. By contrast, a tax on resource ownership would not encourage peoples to refrain from the exploitation of natural resources. Consequently, establishing a global fund would fail to meet the challenges of environmental degradation and global warming (Casal 2011a: 317-320 and Pogge 2011: 336-337). ${ }^{37}$

\section{HOW SECESSION AFFECTS THE SOVEREIGNTY OF PEOPLES OVER NATURAL RESOURCES}

In the preceding section, I have argued that the territorial interpretation of the permanent sovereignty of peoples over natural resources is not in contradiction to demands of global justice. If duties of assistance can be justified on a global scale, nothing stands in the way of reducing present inequalities by taxing resource-rich countries. A problem that has attracted much less interest in recent philosophical debates concerns the distribution of assets (and debts) after the break-up of states. Although in the past three decades a rich literature on the normative assessment of secession has emerged, the process of "political divorce" has not been discussed in much detail..$^{38}$ In order to clarify whether and to what extent separatist states are entitled to the natural resources found on their territories, the distinction between control rights and income rights proves to be helpful again. This distinction suggests a morally more plausible approach to post-secession conflicts than the concept of unlimited sovereignty over natural resources on which international law currently relies. ${ }^{39}$

A state, which results from a legitimate secession, must be granted

37 For a rejection of this criticism, see Steiner (2011: 332-333); for a response to Steiner's defense, see Casal (2011b: 354-355).

38 The few authors who have dealt with questions of distributive justice that arise in the wake of secession have not specifically elaborated on natural resources (Dietrich 2014 and Catala 2017).

39 According to the Vienna Convention on State Succession of 1983, agreements of the predecessor state and the newly independent state regarding state property (Art. 15.4) or state debts (Art. 38.2) "shall not infringe the principle of the permanent sovereignty of every people over its wealth and natural resources". See also Zimmermann (2007). 
control rights over the natural resources that are found within its borders. ${ }^{40}$ If the rump state still had decision making power over the use of these raw materials, the self-determination right of the newly constituted people would be seriously impaired. For the reasons given above, the population of a separatist state might be unable to pursue its specific aims if a third party would be entitled to require the extraction or preservation of natural resources located within its borders. However, income rights are not a precondition for collective self-determination and, therefore, not implied in peoples' sovereignty over natural resources. Contrary to international law, a newly created state is not necessarily entitled to the full amount of intakes, which can be generated from the natural resources located on its territory.

By limiting the concept of resource sovereignty to control rights, important interests of the rump state's population can be taken into account. Both parts of the now divided country may have made large investments in the development of raw material deposits situated in the break-away region. If the exploitation of resources was made possible by joint efforts of the "divorcees", the population of the rump state has a legitimate claim to benefit from the gains. Consequently, the inhabitants of the separatist state are bound to share their resource revenues in a fair manner with their former fellow-citizens. The duty to transfer an appropriate part of the resource revenues to the rump state is, however, limited in two respects. First, the citizens of the rump state are not entitled to benefit from the utilization of raw materials that were still undeveloped or undiscovered at the time of secession. Since their claim to receive some part of the earnings is based on their contribution to the exploitation, it cannot extend to these resources. Second, the duty of the separatist state to share its resource revenues with the rump state will presumably decrease over time. The exploitation of raw materials requires ongoing investments in the technological equipment and the infrastructure that need to be maintained and modernized. The higher the expenditures of the separatist state are, the more diminishes the relative weight of the rump state's former contributions. Hence, the share of the resource revenues to which the citizens of the rump state are entitled will usually shrink in the course of time. ${ }^{41}$

To the first-mentioned qualification it may be objected that the citizens

40 Of course, the question of what requirements a secession must meet to be considered legitimate is a matter of dispute. Different views are expressed, for instance, in Buchanan (2004: 331-400), Miller (1995: 81-118) and Wellman (2005).

41 Since it will be difficult to exactly determine the changing shares of the resource revenues, the second qualification is best understood as a normative guideline for a negotiated settlement of both parties. 
of the rump state had a legitimate expectation to benefit in the future from the exploitation of still undeveloped or undiscovered raw materials located on the separatist territory. Therefore, one may argue, they should receive an appropriate share of the earnings that will be generated from these resources. Here it is important to recall that I only consider cases when the population of the break-away regions had a moral right to create an independent state. Although the inhabitants of the remaining regions may not have reckoned with the secession, they have not been wronged by it. Generally speaking, the expectation of an actor A that some other actor B will not choose an option to which she is entitled cannot ground a moral claim against B. A may perhaps have good epistemic reasons, given her experience or knowledge, not to anticipate B's decision. However, A is not normatively justified in expecting $B$ to forego a morally permissible action. ${ }^{42}$ Hence, if the secession was legitimate, the rump state's population cannot substantiate a claim to benefit from the exploitation of undeveloped or undiscovered resources.

Finally, the question needs to be addressed whether a separatist state has compensatory duties even if it terminates the exploitation of profitable resources. The citizens of the rump state may have made large financial contributions to the development of some raw materials and may, therefore, feel entitled to a fair share of the revenues that would have been generated had the secession not occurred. In my view, in the situation described compensatory claims are for two reasons unwarranted. First, the separatist state might be compelled to continue the exploitation of resources in order to be able to meet its financial obligations. The forced extraction of natural resources might make it extremely difficult, or even impossible, to realize important societal goals. Consequently, the self-determination right of the newly constituted people would be severely undermined by the rump state's monetary claims. ${ }^{43}$ Second, it is generally assumed that sovereign states may reassess and change their energy policies over time. Thereby they do not incur compensatory duties against taxpayers for lost profits, although they may have contractual duties towards private investors. Given that the secession was legitimate, the same moral criteria must apply to the newly independent state as to any other state. Hence, the separatist state can be under a duty to share its resource revenues (to a diminishing degree) with the rump state, but it need not make compensatory payments if it decides to end the extraction and to forego potential gains.

42 For a brief discussion of the distinction between justified epistemic and justified normative expectations, see Meyer and Sanklecha (2014: 370-372).

43 As explicated in section 3.3, the forced extraction of natural resources is likely to have a more negative impact on a people's capacity for self-determination than the forced conservation of natural resources. 
In sum, the here proposed interpretation of peoples' permanent sovereignty over natural resources enables the international community to respond to post-secession conflicts in a balanced way. By granting the separatist state substantial control rights over the natural resources located on its territory the political self-determination of the newly created people can be effectively protected. By restricting the resource-related income rights of the separatist state the justified demands of the rump state's population can be taken into account. The separatists' duty to share their resource revenues with the rump state's population has the additional advantage to provide sensible incentives. Although this duty is qualified in two important respects, it will tend to discourage secessions, which are primarily motivated by economic reasons. Hence, the concept of the permanent sovereignty of peoples over natural resources defended above promises a stabilizing effect on the international order.

\section{CONCLUSION}

In the penultimate section, I have examined three possible explanations for the close connection between a people's right to political selfdetermination and its permanent sovereignty over natural resources as established in international law. I have, first, argued against the attribution of property rights (or similarly acquired jurisdictional rights) to the collectives concerned and I have, second, criticized an instrumentalist view of the relationship between natural resources and political selfdetermination. Instead, I have proposed to understand peoples' sovereignty over natural resources as an aspect of their territorial authority, which is a necessary precondition for actualizing the right to political self-determination.

Based on this interpretation, an important distinction between control rights and income rights can be established. A self-determining people is - within the limits set by the harm principle - entitled to decide on the utilization or conservation of the natural resources located on its territory. However, it has not necessarily a claim to the full amount of intakes that can be generated from the exploitation of these resources. The restriction of income rights allows for reconciling the permanent sovereignty of peoples over natural resources with demands of global justice. In addition, as I have shown in the last section, the here defended interpretation provides a sensible answer to resource conflicts that may arise in the wake of secession. If the population of a rump state has made a significant contribution to the development of natural resources situated in the 
breakaway region, it can be granted a claim to a fair share of the separate state's revenues.

\section{BIBLIOGRAPHY}

Angeli, O., 2015: Cosmopolitanism, Self-Determination and Territory. Justice with Borders, Basingstoke, New York: Palgrave Macmillan.

Armstrong, C., 2010: "National Self-Determination, Global Equality and Moral Arbitrariness", The Journal of Political Philosophy 18: 313-334.

- 2015: “Against 'Permanent Sovereignty' over Natural Resources”, Politics, Philosophy \& Economics 14: 129-151.

- 2017: Justice and Natural Resources. An Egalitarian Theory, Oxford: Oxford University Press.

Auty, R. M., 1993: Sustaining Development in the Mineral Economies. The Resource Curse Thesis, London: Routledge.

Banai, A., 2016: "Self-Determination and Resource Rights: In Defence of Territorial Jurisdiction over Natural Resources", Res Publica 22: 9-20.

Barboza, J., 2011: The Environment, Risk and Liability in International Law, Leiden, Boston: Martinus Nijhoff Publishers.

Beitz, C. R., 1980: “Tacit Consent and Property Rights”, Political Theory 8: 487-502.

Buchanan, A., 2004: Justice, Legitimacy, and Self-Determination. Moral Foundations for International Law, Oxford: Oxford University Press.

Casal, P., 2011a: “Global Taxes on Natural Resources", Journal of Moral Philosophy 8: 307-322.

- 2011b: "Rejoinder to Pogge and Steiner", Journal of Moral Philosophy 8: 353-365.

Catala, A., 2017: "Secession and Distributive Justice", Philosophical Studies 174: 529-552.

Dam-De Jong D., 2015: International Law and Governance of Natural Resources in Conflict and Post-Conflict Situations, Cambridge: Cambridge University Press.

Dietrich, F., 2011: “Changing Borders by Secession: Normative Assessment of Territorial Claims” in The Ashgate Research Companion on Secession, ed. A. Pavković and P. Radan, Aldershot: Ashgate, 81-95.

- 2014: "Secession of the Rich: A Qualified Defense", Politics, Philosophy \& Economics 13, 62-81.

Feinberg, J., 1984: The Moral Limits of the Criminal Law. Vol. 1: Harm to Others, Oxford: Oxford University Press.

- 1986: "Wrongful Life and the Counterfactual Element in Harming", Social Philosophy \& Policy 4: 145-178.

Fleischacker, S., 2013: "Owning Land versus Governing a Land: Property, Sovereignty, and Nationalism”, Social Philosophy \& Policy 30: 373-403.

Gans, C., 2003: The Limits of Nationalism, Cambridge: Cambridge University Press.

Gümplová, P., 2014: “Restraining Permanent Sovereignty over Natural Resources”, Enrahonar. Quaderns de Filosofia 53: 93-114.

Haugen, H. M., 2014: "Peoples' Right to Self-Determination and Self-Governance over Natural Resources: Possible and Desirable?", Nordic Journal of Applied Ethics 8: 3-21. 
Hayward, T., 2006: "Global Justice and the Distribution of Natural Resources", Political Studies 54: 349-369.

Hyde, J. N., 1956: "Permanent Sovereignty over Natural Wealth and Resources", The American Journal of International Law 50: 854-867.

Kolers, A., 2012: “Justice, Territory and Natural Resources”, Political Studies 60: 269-286.

Locke, J., 1960 [1689]: Two Treatises of Government, ed. P. Laslett, Cambridge: Cambridge University Press.

Meisels, T., 2009: Territorial Rights, $2^{\text {nd }}$ ed., Heidelberg et al.: Springer.

Meyer, L. and Sanklecha, P., 2014: "How Legitimate Expectations Matter in Climate Justice”, Politics, Philosophy \& Economics 13: 369-393.

Miller, D., 1995: On Nationality, Oxford: Oxford University Press.

-2007: National Responsibility and Global Justice, Oxford: Oxford University Press.

- 2012: “Territorial Rights: Concept and Justification", Political Studies 60: 252268.

Miranda, L. A., 2012: "The Role of International Law in Intrastate Natural Resource Allocation: Sovereignty, Human Rights, and Peoples-Based Development", Vanderbilt Journal of Transnational Law 45: 785-840.

Moore, M., 2015: A Political Theory of Territory, Oxford: Oxford University Press.

Nine, C., 2012: Global Justice and Territory, Oxford: Oxford University Press.

Pereira, R. and Gough, O., 2013: "Permanent Sovereignty over Natural Resources in the $21^{\text {st }}$ Century: Natural Resource Governance and the Right to SelfDetermination of Indigenous Peoples under International Law", Melbourne Journal of International Law 14: 1-45.

Pogge, T., 2008: World Poverty and Human Rights: Cosmopolitan Responsibilities and Reforms, $2^{\text {nd }}$ ed., Cambridge: Polity Press.

- 2011: "Allowing the Poor to Share the Earth", Journal of Moral Philosophy 8: 335352.

Rawls, J., 1999: The Law of Peoples, Cambridge (Mass.), London: Harvard University Press.

Raz, J., 1986: The Morality of Freedom, Oxford: Oxford University Press.

Risse, M., 2012: On Global Justice, Princeton, Oxford: Princeton University Press.

Ross, M. L., 2015: "What Have We Learned about the Resource Curse?", Annual Review of Political Science 18: 239-259.

Schrijver, N., 1997: Sovereignty over Natural Resources. Balancing Rights and Duties, Cambridge: Cambridge University Press.

- 2010a: Development without Destruction. The UN and Global Resource Management, Bloomington (In.): Indiana University Press.

- 2010b: "Permanent Sovereignty over Natural Resources", Max Planck Encyclopedia of Public International Law, http://mpepil.com.

- 2015: "Fifty Years Permanent Sovereignty over Natural Resources" in Permanent Sovereignty over Natural Resources, ed. M. Bungenberg and S. Hobe, Heidelberg et al.: Springer, 15-28.

Schuppert, F., 2014: "Beyond the National Resource Privilege: Towards an International Court of the Environment”, International Theory 6: 68-97.

Schwebel, S. M., 1994: Justice in International Law, Cambridge: Cambridge University Press. 
Simmons, A. J., 1992: The Lockean Theory of Rights, Princeton: Princeton University Press.

- 2001: “On the Territorial Rights of States", Philosophical Issues 11: 300-326. 1994: An Essay on Rights. Oxford, Cambridge: Blackwell.

— 2011: “The Global Fund: A Reply to Casal”, Journal of Moral Philosophy 8: 328-334

Stilz, A., 2016: “The Value of Self-Determination", Oxford Studies in Political Philosophy 2: 98-127.

Venables, A. J., 2016: “Using Natural Resources for Development: Why Has it Proven so Difficult?", Journal of Economic Perspectives 30: 161-183.

Wellman, C.H., 2005: A Theory of Secession. The Casefor Political Self-Determination, Cambridge: Cambridge University Press.

Wenar, L., 2008: "Property Rights and the Resource Curse", Philosophy \& Public Affairs 36: 2-32.

- 2016: Blood Oil. Tyrants, Violence, and the Rules that Run the World, Oxford: Oxford University Press.

Zimmerman, A., 2007: "State Succession in Other Matters than Treaties", in: Max Planck Encyclopedia of Public International Law, http://mpepil.com. 